\title{
Politeness Strategies in Third Presidential Debate on Foreign Policy between Barack Obama vs. Mitt Romney
}

\author{
Munawwir Hadiwijaya \\ Program Studi Pendidikan Bahasa Inggris IKIP Budi Utomo \\ Jalan Citandui 46 Malang \\ mr.awinwijaya@gmail.com \\ Yahmun \\ Program Studi Pendidikan Bahasa Inggris IKIP Budi Utomo \\ Jalan Citandui 46 Malang
}

\begin{abstract}
Abstrak: Penutur harus pandai menggunakan strategi kesantunan dalam berbicara. Hakikat kesantunan berbahasa adalah etika kita dalam bersosioalisasi di masyarakat dengan penggunaan, permilihan kata yang baik dengan memeperhatikan dimana, kapan, kepada siapa, dengan tujuan apa kita berbicara secara santun. Di dalam debat, meskipun dituntut untuk mampu mematahkan argumen lawan debat, akan tetatpi pendebat juga harus maтри menunjukkan bahwa yang beesangkutan tetap dalam koridor kesantunan agar debat berjalan dengan lancer, seperti yang dicontohkan oleh Obama vs. Romney dalam sebuah acara debat presiden, yang menjadi objek dari penelitian ini. Bagaimana kedua peserta debat tersebut mengaplikasikan prinsip-prinsip kesantunan adalah fokus dari penelitian ini. Penelitian ini menggunakan metode diskriptif kualitatif sebagai desain penelitiannya dengan kerangka berpikir prinsip kesantunan berbahasa Brown dan Levinson. Hasil penelitian menunjukkan bahwa strategi Bald on record digunakan dalam situnsi ketika penutur menginginkan efisiensi maksimal dari ujaran yang mereka hasilkan. Strategi kesantunan positif digunakan oleh penutur dalam kondisi dimana penutur mencoba untuk meminimalisir FTA dengan menunjukkan keakraban. Strategi kesantunan negatif digunakan dalam situasi dimana penutur ingin berfokus pada asumsi bahwa ujarannya mungkin dapat menyinggung mitra tutur. Terakhir, strategi off record digunakan untuk menghilangkan tekanan yang dirasakan oleh mitr tutur. Di antara ke empat strategi tersebut strategi kensantunan positif paling dominan digunakan oleh ke dua peserta debat.
\end{abstract}

Kata Kunci: prinsip kesantunan, martabat, tindak pengancam martabat, debat

In communication, speakers choose the strategies to have polite conversation. People use politeness strategies in order to get their conversation run well and go smoothly. Brown and Levinson (1987) state that recognizes what people are doing in verbal exchange (e.g. requesting, offering, criticizing, complaining, etc) not so much by what they overtly claim to be doing as in the fine linguistics details of utterances. It means that not only speaking in fine linguistics but also considering other's feeling are important. In other word, speaking politeness involves taking account of the other's feeling and being polite person means that he should make others feel comfortable.

Politeness strategies are used by people to ensure asmooth communication and harmonious interpersonal relationship in non-hostile social communication. Those strategies are used for calling forms of oral and written communication.
One of the forms of communication is debate. Debate is a method of interactive and representational argument. Debate is a broader form of argument than deductive reasoning, which only examines whether a conclusion is a consequence of premises, and factual argument, which only examines what is or isn't the case, or rhetoric, which is a technique of persuasion (Goody, 1996).

Moreover, during presidential elections in the United States, ithas become customary for the main candidates (almostalways the candidates of the two largest parties, currently the Democratic Party and the Republican Party) to engage in a debate. The topics discussed in the debate are often the most controversial issues of the time, and arguably elections have been nearly decided by these debates (e.g., Nixon vs. Kennedy). While debates aren't constitutionally mandated, it is often considered a de facto election process. The 
debates are targeted mainly at undecided voters; those who tend not to be partial to any political ideology or party.

There are mainly two reasons in case of selecting third presidential debate between Barack Obama vs. Mitt Romney as the object being analyzed. First, the debate seems to be considered as an interesting current issue in the same manner as qualitative research. Another one, as the primary reason, is that, in linguistic phenomena, Barrack Obama has special characteristics rather than others in terms of being a speaker. the characteristics are not only from his utterances or the way performing his arguments during the debate which is able to influence all the audiences, but also the way of Obama's usage of politeness strategies in arguing and attacking the statements come from Romney which become interesting part of the debate.

Furthermore, this study has relation to the previous researches on the same field. Aini (2003) had examined how the nurses in the hospital used the politeness strategies in therapeutic communication. He found out that there were two kinds of them which were used by the nurses, positive and negative politeness. Another same research conducted by Yuliana (2003) mentions that the people of Probolinggo, East Java which become the object of her study performed politeness strategies in both Madurese and Javanese. Other was conducted by Fatkhurozi (2007) who toke the dialogue between Mia and Her Grandma in "Princess Diaries" Film. The approach for analyzing the phenomena is based on the Scollon and Scollon's Theory of Politeness. He found out that both Mia and her grandma used two kinds of strategies based on Scollon and Scollon's Concept of Politeness, they are involvement and independent strategies.s

Moreover, from the previous studies above, it hasn't been found a researcher who is interested in observing the politeness in a debate. One interesting aspect in debate situation is that, during the debates, participants try to display and enact their intellectual identities. In attending intellectual meetings, one prominent concern of the participants is to put an impression of being intellectually competent without being apparent as making efforts to be called bright. Because of this reason, this study is conducted to uncover the pattern of politeness in a debate especially in third presidential debate on foreign policy between Barack Obama vs. Mitt Romney. Based on the background of the study, the research would like to investigate the following problems: (1) What kind of politeness strategies used by Obama and Romney in third presidential debate on foreign policy? (2) What is the most dominant strategy used by Obama and Romney in third presidential debate on foreign policy?

The main objective of this study is to investigate the use of politeness strategies used by President Obama and Mitt Romney focused on foreign policy in their third and final presidential debate, held Monday, 22 October 2012, at Lynn University in Boca Raton, Fla. Specifically, this study is designed to find out the kinds of politeness strategies used by President Obama and Mitt Romney in the debate and also to find out the most dominant strategy used by them.

There are two kinds of significance in this study, those are theoretical and practical. Theoretically, the research is significant to provide some information about politeness strategies for those who are interested in the study of politeness strategies.

Practically, the result of the research will be beneficial for those who want to deal with understanding language communication, especially in debate. This study is expected to give valuable information to further researchers, students, and readers. For the further researchers, this study is expected to provide the base in analyzing the politeness strategies more deeply. For the students, this study is expected to give useful information in understanding politeness strategies. Then, this study will help the readers who want to know the concept of politeness strategies.

This study is focused on analyzing politeness strategies in third presidential debate on foreign policy between Barack Obama vs. Mitt Romney. The scope of this study is the utterances which contain politeness strategies used by President Obama and Mitt Romney focused on foreign policy in their third and final presidential debate, held Monday, 22 October 2012, at Lynn University in Boca Raton, Fla.

This study limits its discussion on Brown and Levinson's theory of politeness which classifies the strategies of politeness into four categories, those are: bald on record, positive politeness strategies, negative politeness strategies, and off record to become the knife of analysis to process the data found. 
Brown (1987: 4) describes politeness as "behaving in a way that attempts to take into account the feeling of people being addressed." In other words, being polite means that we try to keep our manners or behaviors and our language not to hurt other people's feelings. Moreover, according to Brown and Levinson (1987: 65), politeness strategies are developed to save the hearer's Face. 'Face' here refers to the respect that an individual has for him or herself, and maintain that "self esteem" in public or in private situations.

They (p.76) further argue that the intensity of the threat to Face is expressed by a weight (W) that is related to FTA. Meanwhile, weight is the sum of three social parameters which are:

(a) the rate of imposition (R),

(b) social distance between the speaker and the person addressed (D),

(c) The power that the person being spoken to has over the speaker (P). Thus, intensity of the threat to Face can be formulated as;

$\mathrm{W}(\mathrm{FTA})=\mathrm{R}+\mathrm{D}+\mathrm{P}$

Based on the formula above, we can take an example as below:

a. Excuse me sir, would it be all right if I smoke?

b. Mind if I smoke?

The utterance (a) is usually said by an employee to his boss, while in the same situation, the utterance (b) is might be said by the boss to the employee. Both utterances show the intensity of the threat to face based on the social circumstances.

Based on Brown and Levinson (1987: 61) "Face is derived from the notion of Goffman and English people which is related to the idea of being embarrassed or humiliated, or 'loosing Face'." Since Face is something that is emotionally invested, can be lost, maintained, or enhanced, a person has to pay attention to his interlocutor's Face. In other words, the speaker and the hearer must cooperate in maintaining each other's Face in interaction. The action of maintaining each other's Face called 'Face work'.

Moreover, Goffman in Renkema (1993: 13) introduces the concept of face as an image which is projected by a person in his social contacts with others. Face has the meaning as in the saying to loose fact. Based on the opinion of Goffman, every participant in the social process has the need to be appreciated by others and the need to be free and not to be disturbed. He calls the need to be appreciated as a 'positive face' and the need to be free or not to be disturbed is called as 'negative face'.

While negative face is defined as the desire of every member that he has Freedom of Action as well as freedom of imposition (the desire to not to be disturbed). For example is a father who is in the middle of giving advice to his children expects that his children do not tend to interrupt his speech (freedom of imposition).

Politeness strategies are developed for the main purpose of dealing with the FTA's. We understand the notion of 'face' previously from the dramaturgical theories of Erving Goffman that individuals as social actors perform (present a public self) on the stage of everyday life. The acts that threaten either the negative or positive face of the hearer are called 'Face Threatening Acts' (FTA) (Brown and Levinson, 1987: 65). There are acts that threaten the H's Negative Face such as order, request, suggestion, advice, reminding, threat, warning, offer, promise, compliment and expression of negative emotion. Here, the speaker does not intend to avoid impeding H's Freedom of Action. For example, when you ask someone to lend you some money, you are considered threaten that person's Negative Face. It happens since you have violated his want to be free from being imposed.

In contrast, there are acts that threaten the H's Positive Face such as expression of dissatisfaction, criticisms, complaints, accusation, and insult, disagreement, out of control emotion, irreverence, and bringing bad news about $\mathrm{H}$ or boasting about $\mathrm{S}$, raising divisive topics, and blatant non-cooperation in an activity. All these acts indicate that the speaker does not care about the addressee's feeling or wants. For example, disagreeing with someone's opinion also causes a threat to his Positive Face, as it means that you indicate that he is wrong about something.

Politeness strategies are strategies which used in order to avoid or minimize the FTA that a speaker makes. They are ordered here from most to least threatening: Bald on Record, Positive Politeness, Negative Politeness and Off Record, as illustrated in Figure 2.1. To apply the type of politeness strategies depends on the weightiness of FTA, which determined by three social factors. They are the imposition of the act it self, relative power of the hearer over the speaker and social distance between speaker and 
34 | Munawir Hadiwijaya \& Yahmun, Politeness Strategies in Third Presidential Debate ...

hearer (Brown and Levinson, 1987: 68-74). The more an act threatens the speaker or the hearer's Face, the more polite the strategy. usually shock the hearers, embarrass them, or make them fell a bit uncomfortable. However, this type of strategy is commonly found with

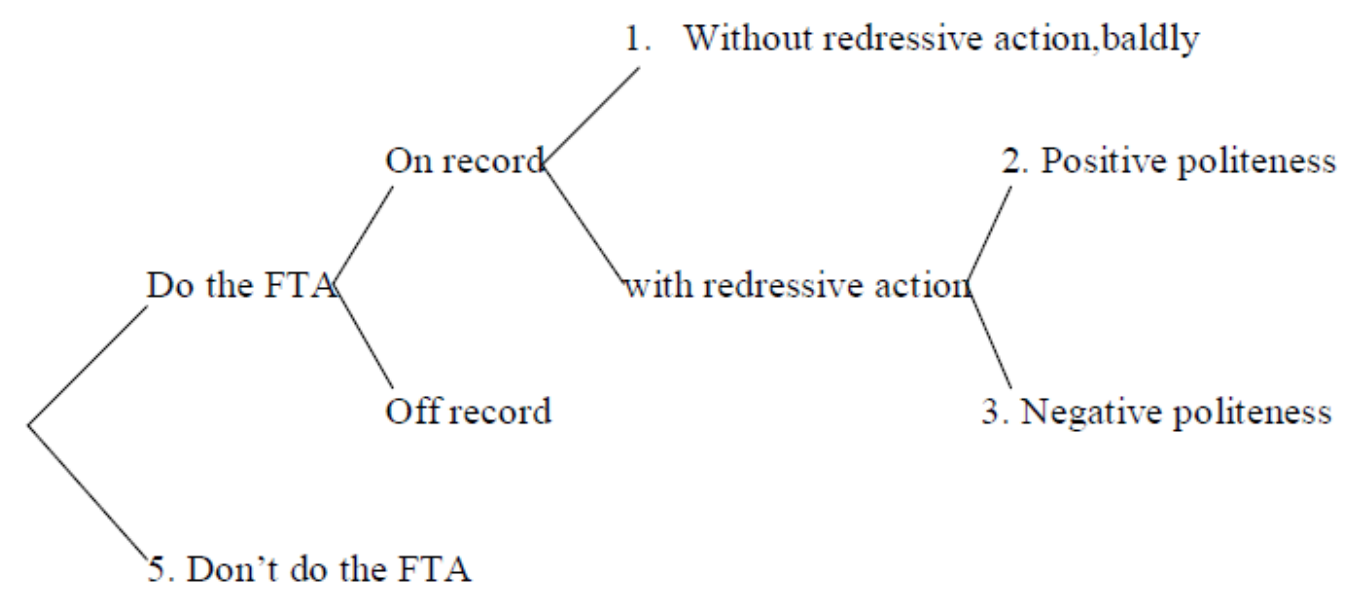

Figure 2.1 Politeness Strategies (adopted from Brown and Levinson, 1987: 60)

Figure 2.1 shows that strategy (5) avoids the FTA and represent no imposition at all. It means $S$ fails to achieve his wants and "Don't do the FTA" is not the concern of this study. For strategy (4), imagine that someone goes to his friend's house and finds that she is just baking cookies, then he says "I feel hungry" by hoping that her friend will offer the cookies to him. It is called Off- Record since he is trying to avoid the direct FTA by asking that utterance. On strategy (3) Negative Politeness recognizes the hearer's Face, but in some way $S$ is imposing to on them. For instance, "I do not want to bother you but, would you mind giving me some of the cookies..." or "I was wondering if..." Next by saying "Is it ok if I tackle the cookie", (2), positive politeness, It shows that $S$ does not only recognize that his hearer has a desire to be respected, but also shows that the relationship is friendly and expresses group reciprocity. Last, Bald on Record strategy (1), it does nothing to minimize threats to the hearer's "Face". Here, $S$ will say his desire directly "I want some of those cookies".

According to Brown and Levinson (1987: 95), whenever the speaker wants to do the FTAs with maximum efficiency more than he wants to satisfy the hearer's Face, $\mathrm{H}$ will choose the strategy of 'bald on record'. Bald on-Record strategy provides no effort by the speakers to minimize the impact of the FTA's. The speakers people who know each other very well, and very comfortable in their environment such as close and family.

Positive politeness is aimed to satisfy the Positive Face of the hearer by approving or including him as a friend or as a member of an in-group. A speaker applies Positive Politeness to give an impression that $S$ wants what H's want or $\mathrm{S}$ wants at least some of H's wants in order to minimize the FTA (Brown and Levinson, 1987: 70). For instance, when the boss asks to his employee, who is subordinate people, to use first name (FN) to him, this is a positive politeness, expressing solidarity and minimizing status difference. Besides that, the positive politeness is a face saving acts which is concerned with the person's positive face which tends to show the solidarity, emphasize that both speakers and hearer want the same thing, and they have a common goal. Another kind of politeness strategies is negative politeness. This strategy used when $S$ wants to show that he cares and respect $\mathrm{H}^{\prime}$ s Negative Face. If $\mathrm{S}$ did or will do an FTA, he will minimize the threat by using apology, deference, hedges and other strategies. Negative Politeness strategies consist in assurances that the speaker recognizes and respects the addressee's negative-Face wants and will not (or will only minimally) interfere with the addressee Freedom of Action. 
This strategy assumes that there might be some social distance or awkwardness between speaker and hearer and it is likely to be used whenever a speaker wants to put a social brake on his interaction (Brown and Levinson, 1987: 129).

\section{Debate}

Debate is contention in argument; dispute, controversy; discussion; especially the discussion of questions of public interest in Parliament or in any assembly. Debate is a method of interactive and representational argument. Debate is a broader form of argument than deductive reasoning, which only examines whether a conclusion is a consequence of premises, and factual argument, which only examines what is or isn't the case, or rhetoric, which is a technique of persuasion. Moreover, Karl Popper, quoted from http://courses.idebate.org/about/debate/ what, states that Debate is a formal contest of argumentation between two teams or individuals. More broadly, and more importantly, debate is an essential tool for developing and maintaining democracy and open societies.

Though logical consistency, factual accuracy and some degree of emotional appeal to the audience are important elements of the art of persuasion, in debating, one side often prevails over the other side by presenting a superior "context" and/or framework of the issue, which is far more subtle and strategic. The outcome of a debate depends upon consensus or some formal way of reaching a resolution, rather than the objective facts as such. In a formal debating contest, there are rules for participants to discuss and decide on differences, within a framework defining how they will interact.

Debating is commonly carried out in many assemblies of various types to discuss matters and to make resolutions about action to be taken, often by a vote. Deliberative bodies such as parliaments, legislative assemblies, and meetings of all sorts engage in debates. In particular, in parliamentary democracies a legislature debates and decides on new laws. Formal debates between candidates for elected office, such as the leaders' debates and the U.S. presidential election debates, are sometimes held in democracies. Debating is also carried out for educational and recreational purposes, usually associated with educational establishments. The major goal of the study of debate as a method or art is to develop the ability to debate rationally from either position with equal ease (Microsoft (®) Encarta (® 2008. (C) 1993-2007 Microsoft Corporation. All rights reserved.). Although informal debate is common the quality and depth of a debate improves with knowledge and skill of its participants as debaters. The outcome of a contest may be decided by audience vote, by judges, or by some combination of the two.

\section{Presidential Debate}

During presidential elections in the United States, it has become customary for the main candidates (almost always the candidates of the two largest parties, currently the Democratic Party and the Republican Party) to engage in a debate. The topics discussed in the debate are often the most controversial issues of the time, and arguably elections have been nearly decided by these debates (e.g., Nixon vs. Kennedy). While debates aren't constitutionally mandated, it is often considered a de facto election process. The debates are targeted mainly at undecided voters; those who tend not to be partial to any political ideology or party.

First, a bit of history on presidential debates. In the United States, they were actually born out of a well-publicized Illinois senatorial debate between Abraham Lincoln and Stephen Douglas in 1858. This debate, with no moderator or panel, was the result of Lincoln following Douglas on his campaign trail around the state, goading him from the audience during campaign speeches. The pair eventually took the stage together for three hours to debate the moral and economic quandaries posed by slavery. The effects of their senatorial debate (Douglas won the seat) wouldn't be seen immediately: Lincoln didn't debate at all during his successful campaign for president two years later in 1860 (http:/ / www. stratfor.com/weekly/ purpose-presidentialdebates).

\section{Third Presidential Debate between Barack Obama vs. Mitt Romney}

The third and final debate between Barack Obama and Mitt Romney, held on October 22nd in Florida on the subject of foreign policy, was not that useful a guide to how the two candidates differ in views of the world. Mr Romney set out to reassure wavering voters that he was not a warmongering heir to George W. Bush, at one 
point declaring: "We want a peaceful planet." He succeeded in this, but in the process made his foreign-policy criticisms of the past several months look like so much rhetorical bluster. Which is the real foreign-policy Romney is now thoroughly unclear.

In the debate, the Republican challenger studiously agreed with Mr Obama on practically everything. He concurred that a diplomatic approach based on sanctions was a viable strategy for blocking Iran's nuclear programme. He grumbled only that sanctions could have been tougher, earlier, and suggested that he would seek to indict the Iranian president, Mahmoud Ahmadinejad, for incitement to genocide (http://www.economist.com/news/ united-states/21565221-barack-obama-performedbetter-mitt-romney-no-one-likely-care-third-time). The subject of the debate, which was very ably moderated by Bob Schieffer, was supposed to be foreign policy. But both candidates managed to pivot to domestic policy time and time again, and for the very good reason that domestic policy is far more likely to decide the election (http://www.politico.com/news/ stories/ 1012/ $82733 \mathrm{html})$

\section{METHOD}

The research deals more with pragmatics and is concerned with politeness strategies. Bogdan and Biklen (1998) described five characteristics of qualitative research: naturalistic, descriptive, process concerned, inductive, and meaning concerned.Qualitativeresearch needs descriptive data which are collected in the form of words or pictures rather than numbers. In this case, the analysis is focused on the data which are the debate between Barack Obama vs. Mitt Romney in third presidential debate on foreign policy.

Moreover, referring to the objective of the research, the study is classified as descriptive qualitative since several typical characteristics of the qualitative design are present in this study. The first characteristic is that this study relies much on the natural setting; the conversations between subjects during the discussion were not under the writer's control. The second, the data of this study are in the form of words rather than numbers. The last, this study is concerned much with the contexts. Every utterances produced by the research subjects is understood on the basis of the contexts. Moreover, the research deals more with pragmatics and is concerned with politeness strategies proposed by Brown and Levinson.

The study is designed to get information concerning with the kinds of politeness strategies used in a debate especially in third presidential debate on foreign policy between Barack Obama vs. Mitt Romney and the functions of their using those kinds of strategies.

The data source of this research was taken from the dialogues which occur in third presidential debate on foreign policy held Monday, 22 October 2012, at Lynn University in Boca Raton, Fla, in which was downloaded from http://blog.fednews.com/presidentialdebate-2012/ accessed on 13 May 2013, between President Obama and Mitt Romney. The data is in the form of conversational excerpts archived from the transcribed conversations. The theory of politeness strategies proposed by Brown and Levinson was used in the analysis.

As the research is a qualitative research, the main research instruments are the researcher himself. The researcher's roles are as the data collector and data analyst.

Moreover, in conducting the research, the researcher used supporting instruments to collect and analyze the data. The supporting instruments are in the form of field notes. It was used to write anything which is not included in the transcription.

The data in this research are the recording file of in third presidential debate on foreign policy between Barack Obama vs. Mitt Romney. The writer took utterance transcriptions of it from internet.

The oral data-the utterances produced by Barack Obama and Mitt Romney during third presidential debate on foreign policy was obtained by downloading from http:// blog.fednews.com/presidential-debate-2012/ accessed on 13 May 2013.

Moreover, some other relevant data is obtained by having field notes. The information such as the gestures of those two persons, the face expressions, intonations and some notes related to the process of debate were taken by using this kind of instrument.

The writer used descriptive qualitative techniques in analyzing the data. After obtaining the data from the data source, they were analyzed in the following steps. (1) Identifying the utterances in third presidential debate on 
foreign policy between Barack Obama vs. Mitt Romney by watching and listening carefully to it which contains politeness strategies based on Brown and Levinson theory. (2) Organizing the data from the script into two categories reflecting the first two objectives of the study: (a) kinds of politeness used by Barack Obama and Mitt Romney and (b) the functions of them.

(3) Reducing the data, involving identification and classification of politeness strategies used. Therefore, any kinds of data which are out of the research problems of this study are omitted. (4) Analyzing, based on the data found, the politeness strategies used by Barack Obama and Mitt Romney, under what situation the politeness strategies are applied, and the reasons why such politeness strategies are chosen. (5) Making conclusion, the general conclusion related to the kind of politeness strategies used by Obama and Romney in third presidential debate on foreign policy and its functions are made.

\section{FINDING AND DISCUSSION}

Before discussing the politeness strategies, it is necessary to elaborate the topics discussed in the recorded data. The data was taken from the third presidential debate on foreign policy between Barack Obama vs. Mitt Romney focused on foreign policy in their third and final presidential debate, held Monday, 22 October 2012, at Lynn University in Boca Raton, Fla. The results show that from the debate, there are 70 utterances identified as the cases of the use of politeness strategies, they are broken down into 8 bald on record strategies used, 31 positive politeness, 27 negative politeness, and 4 off record. However, the writer just takes 34 data which are taken from the members of debate, Obama, Romney, and the moderator's utterances since these selected data can represent all the data.

Data Display of the Politeness Strategies Used

\begin{tabular}{ccc}
\hline \multirow{2}{*}{ Strategies } & \multicolumn{2}{c}{ Number of cases } \\
\cline { 2 - 3 } & Figures & $\%$ \\
\hline Bald on record & 8 & $23.52 \%$ \\
Positive politeness & 15 & $44.11 \%$ \\
Negative politeness & 7 & $20.58 \%$ \\
Off record & 4 & $11.76 \%$ \\
\hline Total & 34 & $100 \%$ \\
\hline
\end{tabular}

The discussion is developed from the notions of: the way the (1) politeness strategies used by Obama and Romney in third presidential debate on foreign policy, (2) the functions of politeness strategies used, and the most dominant politeness strategy used by Obama and Romney in third presidential debate on foreign policy.

\section{Politeness Strategies Used By Obama and Romney in Third Presidential Debate on For- eign Policy}

This section will be the discussion of the findings of the previous presentation. It will be presented item by item in the sequence of politeness strategies: bald on record, positive politeness, negative politeness, and be followed by off-record.

\section{Bald on Record}

The prime reason of bald on record usage is when $S$ wants to do the FTA with maximum efficiency more than he wants to satisfy hearer's face, even to any degree. The speaker which uses this strategy provides no effort to minimize the impact of the FTAs. The effect of this strategy is usually shock the hearers, embarrassed them, or make them uncomfortable with her utterances. Moreover, in the third presidential debate between Barack Obama vs. Mitt Romney on foreign policy, there are eight cases of bald on record based on Brown and Levinson consist of cases of (1) the maintenance of efficiency, intimacy, and equality, such as "I know you...", "I indicated that...", and "I tell you...", (2) non-minimization of FTA for showing how powerful of position the speakers have, such as the utterances: "wrong and reckless policies", "That's the height of silliness", and "You're wrong. You're wrong", and (3) cases of channel noise such as "You can't - you can't well, OK, but..."

\section{Positive Politeness}

The primary reason of the uses of positive politeness strategies based on Brown and Levinson is to redress directed to the hearer's positive face. Speaker provides his effort to minimize the distance between his and the hearer by fulfilling the hearer's wants in some respect. Anyway, in this matter, it is also as a social accelerator that used by the $S$ to indicate $S$ 
wants to come closer to the hearer in order to get what $\mathrm{S}$ wants. Moreover, there are many kinds of positive politeness strategies used by Obama and Romney in third presidential debate on foreign policy such as: Noticing, exaggerating, seeking agreement, avoiding disagreement, presupposing/ raising/ asserting common ground, including both $\mathrm{S}$ and $\mathrm{H}$ in the activity, and giving (or asking for) reasons.

\section{Negative Politeness}

The main focus of negative politeness strategies is for assuming that the speaker may be imposing and intruding on hearer's space. In other words, speaker attempts to minimize the imposition on Hearer or acknowledge H's negative face.

There are some negative politeness strategies according to Brown and Levinson used by Obama and Romney in third presidential debate on foreign policy which analyzed by the writer such as: questioning, hedging, being pessimistic, giving deference, and apologizing.

\section{Off-record strategy}

According to Brown and Levinson, there are two payoffs for off record strategy, there are: a) $S$ can satisfy negative face to a degree greater than that afforded by the negative politeness strategy; b) $S$ can avoid the inescapable accountability, the responsibility for his action that on-record strategies entail. In the other hand, $S$ can take pressure off of the hearer that could be interpreted by hearer as some other acts. Indeed, there are three kinds of off record strategy used by Obama and Romney in third presidential debate on foreign policy, those are: overstatement, the use metaphors, and ambiguous statement.

\section{The Dominant Strategy Used by Obama and Romney in Third Presidential Debate on For- eign Policy}

There are 70 utterances identified as the cases of the use of politeness strategies, they are broken down into 8 bald on record strategies used, 31 positive politeness, 27 negative politeness, and 4 off record. However, the writer just takes 34 data which are taken from the members of debate, Obama, Romney, and the moderator's utterances since these selected data can represent all the data.
Furthermore, the dominant strategy used by Obama and Romney in third presidential debate on foreign policy was positive politeness strategies in which be broken down into nine utterances of Obama's and five utterances for Romney. These phenomena indicate that both Obama and Romney, although, they against each other in the debate and also in the presidential election, they still keep their appreciation to their opponent, since the primary function of positive politeness strategy is to avoid or minimize the FTA that the speaker probably makes.

\section{CONCLUSION AND SUGGESTION}

After analyzing and discussing the politeness strategies used in the third presidential debate on foreign policy between Barack Obama vs. Mitt Romney focused on foreign policy, the writer can conclude that there are many kinds of politeness strategies appear in the debate. Those are: bald on record, positive politeness, negative politeness, and off record strategy.

Moreover, after the writer analyzes the data, He found that President Barrack Obama used the four strategies of politeness. The same thing also happened to Romney who becomes the opponent of Obama in the debate. It is found that by using bald on record, both Obama and Romney show little concern to their addressee. They use this strategy to maintain efficiency, show intimacy, and equality, show how powerful of position they have, and to clarify their opponent's unclear statements due to noises.

Moreover, there are many kinds of positive politeness strategies used by Obama and Romney in third presidential debate on foreign policy such as: (1) Noticing to remind their opponent, (2) exaggerating to give their opponent the feeling of conformability, (3) seeking agreement, avoiding disagreement, presupposing/ raising/ asserting common ground, including both speaker and hearer in the activity to show their cooperation attitude, and (4) giving (or asking for) reasons to ask for clarification.

Negative politeness strategies used by Obama and Romney are as follows: (1) questioning to show doubt and disagreement in smoothened manner, (2) hedging to soften their statements, (3) being pessimistic to show their will to make their opponent comfortable, (4) giving deference, and apologizing to show their respect to their opponent. 
Furthermore, there are three kinds of off record strategy used by Obama and Romney in the debate, those are: (1) overstatement, (2) metaphors, and (3) ambiguous statement, which all of them have function to smoothen their strong disagreement. Because of this study focuses on the usage of politeness strategies used in the third presidential debate on foreign policy between Barack Obama vs. Mitt Romney focused on foreign policy, this study contributes on the improvement of understanding language studies, and so, it will become a direct contribution to the existing knowledge in field of linguistic phenomena. Furthermore, this study can also lead the next researcher who interested in conducting the same field of research as the reference and comparison that might be relevant to the subject of the researcher.

To enrich the pragmatic studies, the writer hopes for the next researcher to conduct research on politeness strategies in the other form of communication model in purposing to expand the area of investigation.

\section{REFERENCES}

Adams, R. Final US presidential debate: Obama and Romney on foreign policy.(Online) (http:// www.guardian.co.uk/world / 2012/ oct/22/final-debate-obama-romney-live, accessed on 03 June 2013).

Aini, L. 2003. A Study of Politeness Strategies Used by Nurses in Therapseutic Communication in RSUD Pare Kediri. Unpublished Thesis. Malang: English Letters and Language Department, UIN Malang.

Brown, P. \& Levinson, S. 1987. Politeness: Some universals in language usage. Cambridge: Cambridge University Press.
Brown, G. and George Y.1983. Discourse Analysis. New York: Cambridge University Press.

Goody, E.1996. Question and Politeness. Cambridge: Cambridge University Press.

Grundy, P. 2002. Doing Pragmatic. New York: Oxford University.

Kitamura, N. 2000. Adapting Brown and Levinson's Theory of Politeness to the Analysis of Casual conversation

Leech, G. 1983. Principles of Pragmatics. London: Longman.

Levinson, S. C. 1983. Pragmatics. Cambridge: Cambridge University Press.

Renkema, J.1993. Discourse Studies: An Introductory Text Book. Philadelphia/

Amsterdam: John Benjamin's publishing Company.

Wardhaugh, R. 2002. An Introduction to Sociolinguistics. 4th Edition. New York: Cambridge University Press.

Wikipedia. United States presidential election debates. (Online) (http://en.wikipedia. org/wiki/United_States_presidential_ election_debates, accessed on 03 June 2013).

Yule, G. 1996. The Study of Language. New York: Cambridge University Press.

Yuliana, D. 2003. Politeness Strategies of Madurese and Javanese in Cross-

Cultural Interaction in Probolinggo. Unpublished Thesis. Malang: English

Letters and Language Department, UIN Malang. 
$40 \mid$ Munawir Hadiwijaya \& Yahmun, Politeness Strategies in Third Presidential Debate ... 